\title{
4
}

\section{Fiji Indians and the Fiji general elections of 2014: Between a rock and a hard place and a few other spots in between}

\author{
Brij V Lal
}

In the September 2014 Fiji general elections an estimated 80 per cent of Indo-Fijians voted for Commodore Frank Bainimarama's newly formed FijiFirst Party (Lal 2014; Larson 2014). ${ }^{1}$ The extent of the support was startling even though Indo-Fijians have a history of splitting their votes more frequently than indigenous Fijians have. In the 1972 general elections, for instance, 24 per cent of Indo-Fijian votes went to the Alliance Party, with that figure declining significantly over the decades as coups and ensuing convulsions soured race relations and deepened the divide between the two communities (Lal 2006a; Ali 1973). However viewed, the Indo-Fijian shift away from traditionally Indo-Fijian parties to FijiFirst is significant, even perhaps historic. Several factors are responsible. On the one hand was the Bainimarama Government's ruthless use of incumbency to its enormous advantage and to the manifest disadvantage of the opposition parties, inventing and bending rules as it went along, and its generous and unaccounted

\footnotetext{
1 I am grateful to Jon Fraenkel, Padma Lal and Patrick and Vanisha Mishra Vakaoti for their comments and advice for revision. The usual disclaimer applies.
} 
use of the public purse for electioneering (Fraenkel 2015). On the other was a deep sense of fear and foreboding among Indo-Fijian voters: fear of revenge and retribution from Fijian nationalists should the regime lose, and foreboding about their future without the illusion of security provided by the Fijian military. Muzzling of the media through coercive decrees, suppressing dissent and disabling rival centres of power (of the trade unions and non-government organisations, for instance, or the Methodist Church and the Great Council of Chiefs) contributed their share of pressure. Then there were those who made hay while the sun shone or, as the local expression goes, an omelette from eggs broken in the melee.

But just as one swallow does not a summer make, so one election, held under a new and controversial constitution promulgated by a political party intent on remaining in power at all cost, cannot tell us much about the future pattern of political culture in a country with a history of military coups. Contrary to the official narrative, Fiji's future stability is far from assured. Nevertheless, what is clear with the advantage of hindsight is that, wittingly or unwittingly, Indo-Fijian voters have for the time being rejected one model of democracy for another, preferring the rule of a single strongman within an overarching architecture of democracy to the principles of representative democracy of the type enshrined in the conventional Westminster system which Fiji had inherited at independence in 1970. There is change, no doubt, but whether that change is an aberration or permanent, superficial or significant, and whether it will necessarily serve the long-term interests of the Indo-Fijians, and of Fiji more generally, remains an open question.

Any analysis of the 2014 Fijian general elections and of Indo-Fijian political behaviour would have to begin with the political environment in which these took place. To begin with, 2014 was clearly not 1970, 1990 or even 2000 (Firth 2012). All the fundamental and familiar markers of the Fijian political framework had changed. The assumptions and understandings which had governed Fijian political discourse for nearly half a century were gone, gone with the leaders who had engineered them, most notably Ratu Sir Kamisese Mara, the long-reigning prime minister and the pre-eminent Fijian leader of the second half of the 20th century, who died in 2004 (Scarr 2008). The 2013 Constitution, introduced in controversial circumstances without public consultation (Kant \& Rakuita 2014), had several features that differentiated it from 
its predecessors. Communal voting was abolished, although not the practice of voting along ethnic lines. The voting age was reduced from 21 to 18, enfranchising an age cohort that had come of age in an environment corrupted by coups and endless talk of more coups and which yearned for another, steadier, coup-free future. A new electoral system, open list proportional, replaced the former alternative vote system of the 1997 Constitution which itself had replaced the first past the post system adopted at independence. These factors influenced the response of Indo-Fijian voters and the outcome of the elections.

The years since independence had seen Indo-Fijian society change dramatically (Lal 1992; Taylor 1987). In 1970, Indo-Fijians constituted around 50 per cent of the national population. They had overtaken the indigenous Fijians during the Second World War, spawning deep fears among Fijians and Europeans of 'Indian domination'. That fear, whether real or manufactured for political purposes, determined the course of Fiji's political development as it entered the decade of decolonisation in the 1960s (Lal 2006a). Fijian leaders refused to countenance any change towards internal self-government or independence except on their terms. This included the demand for the full retention of the communal system of voting and a tacit acknowledgement of the principle of Fijian political paramountcy in the governance of the country. In other words, Fijian leaders would accept change, including independence, only if they were assured of political control (Norton 2012). A contrived political arrangement, with communal representation and European overrepresentation at its heart, devised by the departing British, delivered that outcome, papering over cracks regarding fundamental issues which divided the country.

Fiji enjoyed fragile political stability during its early post-independence years, but beneath a placid surface and feel-good atmosphere lurked fears and phobias that would wreck its prospects. Fiji was a symbol of hope to the modern world, Pope John Paul II had intoned during his fleeting visit to Fiji in 1985, but that was more comforting rhetoric than a reflection of reality. ${ }^{2}$ Fijian control of the government depended on unity among Fijians and enough disunity among Indo-Fijians for Fijians to win power. But neither group was homogenous, divided as

2 The Fiji Visitors Bureau turned the Pope's words into 'Fiji: The Way the World Should Be' for tourism promotion. 
they were (and still are) along regional, religious and cultural lines. Sakeasi Butadroka's Fijian Nationalist Party exposed the fissures among Fijians by polling 25 per cent of the Fijian communal votes in the April 1977 elections, enough to cause the defeat of the ruling Alliance Party. The lesson was quickly relearnt that Fijian political solidarity was the sine qua non for Fijian control of government. To that end, the Alliance made strenuous efforts, reclaiming lost ground with a handsome majority in the September elections of that year, helped by a massive split among Indo-Fijians about why they were unable to form government after narrowly winning the elections in April (Lal 2009b). The embers from that distant split glowed for decades afterwards, energising factions and divisions that debilitated IndoFijian politics, and still do.

But the Alliance's victory had come at a cost not fully appreciated at the time. It irrevocably fractured the multiracial foundations of the Alliance Party. Its pro-Fijian tilt, evident in the appointments and promotions in the civil service, the allocation of tertiary scholarships and the reservation of Crown land, among other things, saw many founding fathers of the Indian Alliance, including Sir Vijay R Singh and James Shankar Singh, both former cabinet ministers, joining the National Federation Party (NFP). In 1982, when the NFP (24 seats) came close to defeating the Alliance Party (28 seats), the Great Council of Chiefs (GCC), meeting at the historic island of Bau and opened for the first time by a reigning British Monarch, passed resolutions to change the Constitution to entrench permanent political control of government (Lal 2009a). When the Alliance was defeated at the 1987 polls by a nominally multiracial coalition of the Fiji Labour Party and the NFP, the month-old government was overthrown in a military coup carried out by Lieutenant-Colonel Sitiveni Rabuka, the third-ranking officer of the Fiji Military Forces, tacitly supported by the leaders of the defeated Alliance Party and by Fijians more generally. 'Fijian rights in danger' was the catch cry, and it caught on. The depth of Indo-Fijian anger and hurt caused by the coups was not fully apprehended at the time. Two decades later, Commodore Bainimarama would tap into it to his great electoral advantage.

The goals of the coup were entrenched in the decreed 1990 Constitution, allocating a disproportionate number of seats in parliament to indigenous Fijians, abolishing all multiracial voting in favour of communal voting, decreeing a race-based, legally unchallengeable, 
affirmative action programme, and reserving the offices of prime minister, governor-general, commissioner of police and commander of the military and heads of important government bodies (such as the civil service) to Fijians. The Methodist Church, one of the principal instigators of the coup, added fuel to the fire by demanding a strict observance of the Sabbath, known popularly as Sunday Ban. For that agenda of religious zealotry, it would pay an incalculable price two decades later. And the Taukei Movement, which had morphed into existence from a diverse group of Fijian nationalists soon after the 1987 elections, demanded the complete fulfilment of the 'aims of the coup'. Violence was threatened and begun in some places and leases to Indo-Fijian tenants were not renewed. Race relations in Fiji were strained to breaking point in the post-coup years.

The Indo-Fijian reaction to all this was to try to emigrate. Emigration had been taking place in small numbers since the 1970s, mostly to North America and the United Kingdom, but after the coup that trickle turned into a torrent. In two decades, over 120,000 IndoFijians, mostly well-educated professionals, emigrated, depriving the country of much needed skill and talent (Chetty \& Prasad 1993). Many departed deeply embittered and their sense of unjust treatment and rejection continued unabated for decades afterwards. Most never forgave Rabuka for the coups, despite his repeated pleas for forgiveness and his convincing claim that he had acted at the behest of others (Sharpham 2000). Revenge and retribution loomed large in their minds, however vocally denied. The shoe, as the saying goes, was finally on the other foot or, to use a colloquialism, Fijians were now tasting their own medicine. So when Commodore Frank Bainimarama deposed the Qarase government in 2006, many in the Fijian diaspora openly supported him, as they still do, deriving perverse satisfaction at the treatment of the Fijian nationalists by the Fijian military, an eventuality they had never contemplated before. No one had: a Fijian military publicly taking on the Fijian establishment and winning. In 2014 the overwhelming majority of Indo-Fijian voters voted for Bainimarama's party. ${ }^{3}$ His well-publicised visits to Sydney and Auckland to thank his supporters and benefactors, mostly Indo-Fijians, was proof enough of that. Bainimarama's words at the United Nations General Assembly in

3 The 2013 Constitution allowed Fiji nationals living overseas to vote if they were properly registered, whereas before, voters had to be resident in Fiji for two years before the elections, the residency requirement exempted for those on officially authorised absence overseas. 
September 2013 were music to their ears: the coup-inspired emigration of Fiji citizens was 'one of the most shameful episodes of our history', he said, 'and I determined that this must never, never happen again. We must never allow a fellow citizen to be a second-class citizen, to be less than the equal of his neighbour'. No Fijian leader had ever spoken such words of remorse and regret in this way before an international audience.

The massive demographic transformation in Fiji was accompanied by profound changes in the life of the Indo-Fijian community post-1987. None was more significant than the changes in the sugar industry, once the lifeblood of the economy but now in visible decline (Lal 2009b). One cause of this was the non-renewal of 30-year-old leases expiring under the Agricultural Landlord and Tenant Act. Leases were not renewed for many reasons. Among them was the genuine desire of some landowners to join the industry as cultivators themselves, attracted by the possibility of making a decent living they saw, or thought they saw, Indo-Fijian tenants making. Closer acquaintance would reveal the appearance of prosperity to be deeply deceptive. Many Indo-Fijians were actually keen to give up farming altogether for a more regular cash income just when Fijians wanted to come in. But political motivation was not far behind. Under Marika Qarikau, the fiercely, almost irrationally, nationalist head of the Native Land Trust Board, an implicit condition for the renewal of leases was IndoFijian acceptance of Fijian political supremacy. Land was power, Fijian power, and he wanted to extract the maximum concession from its users in a simple quid pro quo.

Non-renewal led to an exodus of displaced tenants from the sugar cane belts of Fiji, especially northern Vanua Levu, on an unprecedented scale. Squatter settlements mushroomed around south-eastern Viti Levu, clogging the Suva-Nausori corridor. Life in these settlements was plainly squalid: there was no running water, electricity, sewerage facilities, employment or educational opportunities. But the evictees had nowhere else to go and no one would have them. In the Cunningham squatter settlement in Suva, the Fijian landlord demanded money for the conduct of religious functions by his Indo-Fijian tenants. Refusal to pay, it was clearly understood, would mean immediate removal. To these people living at the edge of poverty and destitution on the sufferance of others, with little hope or optimism, talk of democracy and good governance and the disclosure of the Auditor General's 
report, withheld since 2006, was just that: talk, academic talk. They had heard of such things before, to no avail. What they wanted was relief and respite from misery.

Here the Bainimarama regime had the upper hand, freely dispensing goods and services from the public purse. Most importantly, the regime promised squatters on state land 99-year leases, a dream come true for hundreds who had never imagined a place of their own, and their gratitude to Bainimarama was unbounded. The government also addressed, through active military patrols, the perennial problem of violent burglary in urban and peri-urban areas. On this frontier of lawlessness and violence, the voters knew that only Commodore Bainimarama could deliver. Often, the protocols of natural justice were blatantly breached. But the savage beatings of escaped prisoners beamed around the world to great consternation over the abuse of human rights in Fiji meant little to the squatters, who were often themselves targets of violent crime. They saw Bainimarama as the upholder of law and order, a leader who was finally on their side. The impression created was of a government at last caring for a group that had long lived literally and metaphorically on the unlovely fringes of society. They therefore rallied behind FijiFirst, as indeed did those who, following the decline of the rural sector, were making a meagre living in urban and peri-urban areas as casual labourers, domestic helpers, mechanics, drivers, or carpenters. Rural decline increased over some time, and will continue to swell the numbers of the desperate urban poor.

Bainimarama's rhetoric justifying the coup also attracted many Indo-Fijians to his side. His was not a coup, he said repeatedly, if unconvincingly, in the face of undeniable evidence, it was a 'cleanup campaign'. He wanted to cleanse the country of corruption. His call resonated with ordinary citizens, who knew in their bones that greasing the palm had become an endemic feature of life in the country, and that things were getting worse by the day, not better. Many Indo-Fijians therefore gave him the benefit of the doubt, and their early support bought the military regime valuable time to consolidate itself. By the time people saw that there was more to the coup than what the Commodore had claimed - that corruption and mismanagement in various guises were alive and well, that what was alleged was never actually proven in a court of law (no big fish were ever caught) — it was too late. 
Over time, Bainimarama, with the help of adroit image makers, including the American public relations company Qorvis, specialists in refurbishing the image of dictators and tyrants around the world, was portrayed as a selfless soldier embarking on a path to remake Fiji into a modern, vibrant, non-racial society, with Singapore as a model in mind. He was steadily transformed in the public eye from a tongue-tied, temperamentally volatile, short-fused military strongman into a man of the people, an appealing leader, modest and engaging, photographed sitting cross-legged on a mat with cheering uniformed school children, sharing a cup of tea with rural IndoFijian housewives, inspecting government projects in shorts and floral bula shirt. No leader had done that before. His 'visit diplomacy' to previously neglected areas in remote regions was good theatre: on horseback, riding through stony rivers and rough terrain, with admirers in tow. Would a 'dictator' ever do that, people asked? He was anti-politics, he said, and blamed 'old' politicians for all the ills of Fiji's past, overlooking the inconvenient fact that several 'old' politicians who had played key roles in previous coups (such as foreign minister Inoke Kubuabola) were serving in his own cabinet. And not altogether subtly, Bainimarama made it clear that it was he, and he alone, who stood between chaos and stability. There would be no coup as long as he was in charge, he told voters. People believed him. They had no reason not to. He was, after all, a former military commander still in touch with his former troops, his eyes and ears still firmly watching and listening to them.

Of all the leaders standing in the elections, Bainimarama was the only one who had the unquestioned loyalty of the military, whose leaders had said often enough that they would prefer him to continue. It was understood, though it did not need to be said, that the military would move in 'to protect the Constitution' if Bainimarama was dislodged. Some political parties had questioned the immunity provisions of the 2013 Constitution, which spawned fear and anger among the rank and file of the military. Bainimarama was on their side. The military needed him as much as he needed them. Mutual self-interest was set in concrete. No one wanted another coup. The attraction of stability and security to a people long at the receiving end of previous coups counted for a lot. People reposed their faith in the coup leader. He was a strong man of action. As he often said, time for talk was over, time for action was now. He had stood up to the GCC and the Methodist Church 
and hobbled them unceremoniously. He had stood up for Fiji against international opposition to his regime. Finer points about democratic principles and implications of the government's policies in the long term, and the inherent dangers of relying on the whims of one man to govern, did not register with the voters. It was often said that nothing good had happened in Fiji until Bainimarama had come on the scene, and that Fiji would revert to its failed past without him at the helm. It was a familiar tactic of military dictators and authoritarian leaders around the world, who portray themselves as the very embodiment of the national spirit, indispensable to the destiny of the nation. Rabuka had done that in 1987 and Bainimarama was doing it now.

This narrative was given unfettered play in the local media, operating under severe restrictions imposed by the Media Industry Development Decree (29/2010). The Fiji Sun newspaper became an unabashed cheerleader for the regime, with screaming front-page headlines praising the government for everything it did or purported to do, while belittling the motivations and modus operandi of its opponents. Fiji had not seen such grovelling journalism before nor such blatantly biased reporting. Unsurprisingly, Commodore Bainimarama was the newspaper's choice for the 'Person of the Year'. Radio stations, both commercial and state-owned, and the FBC television station, were similarly pro-regime. The national broadcaster was run by the younger brother of the regime's attorney general. A prominent Indo-Fijian radio announcer, a household name among Indo-Fijians, pretended neutrality in her questioning of candidates who appeared on her show, but then on the eve of the elections suddenly resigned to stand for Bainimarama's party. The chief executive officer of the Media Industry Development Authority similarly professed impartiality but (unsuccessfully) stood for FijiFirst. ${ }^{4}$ It was disturbing to see such boundaries crossed with such impunity and in full public view. Decency demanded some distance, but none was forthcoming. Now anything was possible, any transgression forgiven, if you were with FijiFirst. ${ }^{5}$

4 In early 2016, Matai Akauola, chief executive officer of the Media Industry Development Authority, entered parliament under the d'Hondt system of voting when a seat became vacant on the government benches.

5 By contrast, students who campaigned for rival political parties were threatened with the cancellation of their scholarships, even as the regime encouraged the participation in politics of young people. 
In the upshot, the people heard only what the military regime wanted them to hear while neutral or contrary voices were noticeably absent from the public domain. The Media Authority, for its part, mouthed platitudes about fairness and responsibility and accuracy and balance in reporting, but it was in truth itself nothing more than a coercive and compliant instrument of and for the regime. ${ }^{6}$ Critics took to social media, but ordinary folk in the countryside without access to the Internet were innocent of the contrary views and voices floating in the cyber traffic. ${ }^{7}$ In the end, the regime's manipulation of the media was as unprecedented as it was complete; it had learned well from the example of authoritarian regimes around the world that consolidation and unhindered and unaccountable exercise of power required a pliant media. And it had all the power in its hands to bend the media to its knees (by giving Fiji TV a six-month license, for example, or imposing huge fines for breaches of the Media Decree, and by restricting foreign ownership of the local media).

Several aspects of the 2013 Constitution helped to attract IndoFijian voters to Bainimarama's FijiFirst Party. One was the abolition of communal voting that had been a defining feature of all Fiji constitutions from the early 20th century (Ali 2007). 'One person, one vote, one value' was the new mantra. In truth, all votes were not equal under the open list proportional system, as the results showed, but what the regime said went. A common roll had been the catch cry of the Indo-Fijian community since 1929, when they first got the franchise, and it had been the signature platform of the NFP in the decolonising decade of the 1960s (Lal 1997). FijiFirst told Indo-Fijian voters it was doing nothing more than meeting a demand the leaders of the Indo-Fijians had been making for generations and therefore deserved its votes, not its condemnation. To see former staunch NFP members such as Praveen Bala (now the minister for housing and local government) in the FijiFirst line-up muddied the waters. Atul Patel, the eldest son of the founding father of the NFP, AD Patel, endorsed this common roll platform of FijiFirst and Faiyaz Koya, the elder son

6 Petitions asking for the investigation of biased reporting from pro-regime sources and their refusal to publish views critical of the regime were routinely ignored. For instances, see blog site 'Wadan Narsey on Fiji - for fairness and freedom'.

7 The most trenchant critiques of the practices and policies of the Bainimarama Government appeared on Coupfourpointfive and on Wadan Narsey's 'Fiji - for fairness and freedom'. 'Fijileaks' made important revelations. On the pro-regime side were 'Grubsheet' and to a lesser extent Cros Walsh's blog site 'Fiji: The Way it Was, Is and Can Be'. 
of another NFP founder and opposition leader, Siddiq Koya, stood as a candidate for FijiFirst and is now the minister for trade and tourism (after a few short days as attorney general). ${ }^{8}$ Their actual and virtual presence behind Bainimarama swayed many voters, who were asking why the NFP was opposing a man who was giving them what the party had been asking for all along: political equality, equal citizenship and a common roll.

On the surface, the question was compelling: why, indeed? The truth was that Bainimarama's brand of strongman, military-backed democracy was not what the NFP had been fighting for. Their quest all along had been for genuine representative democracy, with, right at the heart of it, a robust parliament of men and women elected in their own right rather than riding the coat-tails of their leader. Their platform was for a parliament that would be the ultimate guardian of the country's freely adopted, rather than unilaterally imposed, Constitution; not for an unelected, ethnically lopsided military as the protector of multiracialism and as the arbiter of the national interest. NFP had stood all along for a democracy where power flowed from the ballot box, not from the barrel of a gun. That FijiFirst invoked the name of the NFP in support of its campaign platform was as incomprehensible as it was ironic.

Another feature of the 2013 Constitution that had a bearing on the outcome of the 2014 elections was the lowering of the voting age from 21 to 18. This was recommended by the Reeves Commission in 1996 (Reeves, Vakatora \& Lal 1996) but was rejected by a subcommittee of the Parliamentary Select Committee, chaired by none other than Inoke Kubuabola, on the grounds that in Fijian culture 18-year-olds were considered children, not adults, to be seen rather than heard. ${ }^{9}$ In 2014, a third of voters were below the age of 30. They had come of age during an era of coups in Fiji. They had very little knowledge or understanding of the country's past and, more to the point, no interest in it. History was rarely taught in schools, and what little was taught was sanitised, brushed clean of the mud and muck of the past, ignoring the unarguable fact that Fiji had a fractured past with little common, unifying narrative. The new generation was obsessively focused

8 Though his younger brother, Faizal Koya, stood for the NFP, saying 'I was born in NFP and I will die in NFP'.

9 This I base on conversation with a member of the committee. 
on the Internet-dependent present. Not the book, but Facebook, was their source of information and knowledge and enlightenment. They believed Bainimarama when he blamed Fiji's ill-fated past on corrupt politicians; they believed him rather than the obvious truth that it was the military, aided and abetted by some 'old' politicians, which was the real cause of Fiji's problems. They liked his empowering rhetoric of non-racialism and common citizenship, his standing up for Fiji against Australia and New Zealand (though they all secretly hope to migrate there one day and not to Fiji's new-found friends in Iran and North Korea). And reflecting an international trend, a rich vein of anti-political sentiment ran among the youth of Fiji, to Bainimarama's clear benefit. This is not to say that all young people voted for FijiFirst, but a substantial number did, out of a curious combination of apathy, indifference, naiveté, and misguided enthusiasm.

The new open list proportional system worked to Bainimarama's great benefit. In the new system, the 50 seats in the House of Representatives had to be contested from a single national constituency, dispensing with the constituency boundaries of the past. Voters had to vote for a single candidate (with no indication of their name or party affiliation), with the vote for the individual candidate being automatically counted for his or her party. Seats in parliament would be allocated in proportion to the votes a party won. All parties and independent candidates would have to meet the 5 per cent threshold for victory. Theoretically, the open list system gives the voters, not the party, the power to choose whom they vote for, but FijiFirst encouraged voters to cast their vote for one person, party leader Frank Bainimarama. And that is precisely what happened. Bainimarama got 202,459 votes, nearly 70 per cent of the votes cast for FijiFirst and 40.8 per cent of all the votes cast. The system delivered handsomely for FijiFirst, but whether it augurs well for representative parliamentary democracy is another matter. What happens when Bainimarama is no longer around? Is Fiji fated to be governed from now on by strong men (and perhaps women too) backed by the military within an overarching illusion of democratic governance? In 2009, I wrote: 'A militarized democracy seems in the offing in Fiji' (Lal 2009a, p. 444). Sadly, that prospect is looking more and more likely.

Support for Bainimarama and his party seems to have been fairly widespread across the Indo-Fijian community. Major Indo-Fijian businessmen were in his camp, with financial donations and 
public expressions of support. Among the most prominent of them were CJ Patel, the Tappoos, the Damodars and Gokals, the Dewan Maharajs and owners of big transport and construction companies. Their commitment to Fiji is questionable, as many have substantial assets outside the country and often their families too, with permanent residency papers in order. It is a truism that businessmen everywhere have a cosy relationship with those in power, but the Fiji business community seems to be a particularly myopic lot. There is no sense of loyalty or allegiance to any cause or ideology beyond turning a profit for themselves. They will readily embrace the next person in power, whatever their political ideology, as long as their coffers are full.

Less easy to explain is the support given by Fiji's educational and moral leaders. The vice chancellor of the University of the South Pacific (USP), Rajesh Chandra, an academic bureaucrat par excellence, was a strong supporter of the coup and its leader from the beginning. His staff took his cue, fearful of reprisals. USP's most vocal anti-regime academic, Wadan Narsey, was forced to resign from the university, with the vice chancellor acceding to the military regime's demand. Chandra knew which side of the bread was buttered, as the expression goes in Fiji, but he was also embittered by the denial, unfair as he saw it, of the top job at the regional university some years back because of Fiji's refusal to support his nomination. This was his way of exacting revenge. The vice chancellor of the Fiji National University (FNU), Ganesh Chand, a former Labour politician, was also in the Bainimarama corner, both by choice as well as by necessity. The FNU is a government-funded institution, and not all members of staff were always supportive of him for a variety of reasons, both personal as well as political. Despite his services to the regime, Chand was removed from his position in December 2014. For the historical record, not all Indo-Fijian academics in Fiji or in the Fijian expatriate community were with the regime. There were many, myself included, who opposed the coup through their writings and interventions in the media, but media censorship in Fiji and other forms of overt and covert harassment ensured that contrary narratives did not reach the mainstream public. We mostly talked in the cyberspace through emails and blog sites and Facebook accounts.

From abroad, retired academics in the twilight of their careers and other former Fiji professionals returned to lend support and write in praise of the regime and its leader, ostensibly convinced by the 
regime's rhetoric of creating a new Fiji. Most had left Fiji disillusioned after previous coups, and were returning now to settle old scores and to set things right, often for lucrative fees or appointments and the small, transient privileges of a fading limelight. Some were no doubt diligent, hoping to use the 'opportunity' of the coup to restructure Fiji's political culture towards greater non-racialism and accountable and effective governance. The National Council for Building a Better Fiji became the vehicle for their effort on the clear premise that all changes made would be within the overarching framework of the 1997 Constitution. Bainimarama gave that undertaking, but then proceeded to abrogate the Constitution in April 2009 after the council had completed its work and given the coup leader his much-heralded roadmap back to parliamentary democracy. He also discarded the process of political dialogue he had been urged to undertake by the Commonwealth, among others. He reneged on his promise to the Pacific Islands Forum to hold elections in 2009. Promises were made only to be broken at will. The Commodore tactically outmanoeuvred everyone; in the end, he had the last laugh.

It was often said before and during the campaign that the 2006 coup was a Muslim coup. This was supposedly due to the support for it, vocal or tacit, by many prominent Muslims, such as Aiyaz SayedKhaiyum, Shaista Shameem, former head of the Fiji Human Rights Commission, and her younger sister and former high court judge Nazhat Shameem, now in Geneva as Fiji's ambassador to the United Nations after a short stint as a private legal practitioner in Fiji and destined, many believe, to even higher offices in Fiji. ${ }^{10}$ The visible presence of Muslims in statutory organisations and government bodies reinforced that perception. But Muslims did not instigate the coup; ${ }^{11}$ they were as divided over the event as other communities, and there are opportunists among Muslims as there are in other groups. What is beyond doubt, though, is that over time, as the picture of the political landscape became clearer, and realisation dawned that Bainimarama would be around for a long time, Muslim support firmed up for

10 Michael Green (2013, p. 186) writes about Nazhat Shameem's deep disappointment with the Qarase government for not nominating her for an international judicial post, urging the New Zealand government to sponsor her instead. Only Shameem will ever know if her sense of disappointment with the Qarase government was sufficient for her to adopt a 'softer' approach to the coup and all that followed.

11 Among the strongest opponents of the coup were Shamima Ali of the Women's Crisis Centre, and Imrana Jalal, a human rights lawyer, both Muslims. 
FijiFirst. They voted in very large numbers for the party. Without that, Aiyaz Sayed-Khaiyum, widely distrusted among Indo-Fijians and among most Fijians for his controlling ways, confrontational approach and palpable love of power, and whose large hand was seen in the dismantling of many Fijian institutions, would not have got the votes he did $(13,753$ or 2.8 per cent of the votes cast), more than the total votes cast for the Fiji Labour Party.

But Muslims were not the only ones who supported the military regime. It was the same in other communities as the reality of Bainimarama's determination to remain at the helm sank in. The leaders of Arya Samaj were among its early supporters, with one of them, former high school teacher Kamlesh Arya, appointed high commissioner to Australia without any discernible qualification for that important position. The leaders of the largest Fijian Hindu organisation, the Sanatan Dharma, were not far behind; its then national president Dewan Maharaj, the owner of Quality Print, was among the early prominent backers of the regime. One of the schools in Nausori run by that organisation invited Bainimarama for a function and the welcoming ceremony included washing his feet while he sat on a chair smiling enigmatically, whether in bemused amazement or in genuine puzzlement at this gesture it is difficult to say. The abasing symbolism was arresting as an indicator of desperation. The ceremony is normally performed at serious religious or ritually significant occasions (washing the feet of deities, for instance, or formally welcoming a bridegroom at a wedding by the bride's side), not for ordinary mortals, let alone politicians. Self-interest obviously played a part as organisations vied for government handouts. There were many Hindus who made a show of supporting Bainimarama to prevent him from falling completely into 'the Muslim camp'. But there were other factors as well. Bainimarama's firm rejection of the Methodist Church demand (and the Social Democratic Liberal Party's (SODELPA) also) that Fiji become a Christian state was widely welcomed by Hindus and Muslims. Many had witnessed at first hand the ugly religious bigotry of the late 1980s - the Sunday Ban and the ransacking, looting and burning of Hindu and Muslim places of worship - and they did not want those episodes ever to be repeated. Bainimarama's confrontational attitude towards the Methodist Church, preventing it from holding its annual conferences and insisting that the church dissociate itself from party politics, was welcome among most Indo-Fijians. 
Alternative political parties could not match what FijiFirst had to offer the Indo-Fijian voters. Let us take SODELPA. This was the old Soqosoqo Duavata ni Lewenivanua (SDL) under a new name, fulfilling the requirement that all political parties have English names. ${ }^{12}$ SDL held bad memories for most Indo-Fijians. Its pro-Fijian policies under the Qarase government (the 'Fijian Blueprint', scholarship programs for indigenous Fijians, subsidies to Fijian-only schools, among others) had deeply disenchanted many. Racist utterances by some of its parliamentarians (Asenaca Caucau, for instance, who likened IndoFijians to noxious weeds and went un-reprimanded) were not forgotten or forgiven. Insult and humiliation are hardly ever forgotten among Indo-Fijians; hurtful memories last a long time. The renamed party began with a progressive agenda, but soon started espousing what can broadly be described as a pro-Fijian platform. Many Fijians were understandably angry with the Bainimarama regime for its dismissive policies towards Fijian institutions and protocols, such as abolishing the GCC, using 'Fijian' as the name for all Fijian citizens irrespective of ethnicity, appointing the chairmen of provincial councils, altering the formula of land rent distribution, and dismantling many race-based affirmative action programs.

Hoping to tap into what appeared to be a swelling pool of indigenous Fijian resentment and anger about the regime's policies, SODELPA soon jettisoned any pretence of being a multiracial party, becoming, instead, the vehicle for indigenous Fijian views and concerns. The GCC would be brought back, the party said, Christianity could become the state religion, and the name Fijian would be reserved for indigenous Fijians only. In short, SODELPA once again became the champion for the cause of Fijian paramountcy, though of a more subdued variety than that demanded by the supporters of the 1987 coup. It had little to say to the non-indigenous citizens of Fiji. It fielded only three Indo-Fijian candidates out of 50, among them a former SDL minister, George Shiu Raj, and one of the founders of the People's Democratic Party, Nirmal Singh. They all polled miserably. SODELPA's Fijian reach was strong but its urban base was fractured. The party must adopt a broader, more non-ethnic platform if it is become a serious contender for power in Fiji.

12 Under the Political Parties (Registration, Conduct, Funding and Disclosures) Decree 4/2013. The Decree also required all parties to register or re-register with 5,000 signatures from registered voters, with specified numbers from each of the country's four administrative divisions. 
Indo-Fijian voters had three other parties to choose from: the Fiji Labour Party (FLP), People's Democratic Party (PDP) and the National Federation Party (NFP). None of them got the traction they hoped for. FLP's fate was particularly tragic, winning only 11,670 (2.4 per cent) of the votes cast and for the first time in its history without a seat in parliament. Formed in 1985, the party had won government in 1987 in coalition with the NFP, only to be overthrown in a military coup after a month in office. Its founding leader, Dr Timoci Bavadra, died in 1989, and was succeeded by the long-time trade unionist Mahendra Chaudhry, secretary of the Fiji Public Service Association, after a short stint at the helm by Bavadra's widow, Adi Kuini Bavadra. Adept and politically astute, Chaudhry was also in a hurry to wrest the leadership of the Indo-Fijian community from the NFP, determined, in his own words, to 'finish NFP off' (Lal 2009a). To that end, throughout the 1990s he deployed his considerable political capital, emerging victorious in the 1999 general elections and becoming the country's first Indo-Fijian prime minister. But his government, too, was overthrown in a quasi-coup after a year in office. The policies of his successor, Laisenia Qarase, kept Chaudhry out of government despite the power-sharing provisions of the 1997 Constitution by offering Labour miniscule ministries of no significance. ${ }^{13}$ By the time Qarase honoured the power-sharing formula after the 2006 elections, Chaudhry's cup of disillusionment was full. He concentrated all his efforts on derailing the Qarase government, in which several of his own senior party members were ministers, though he himself had opted to stay out of the Cabinet (Green 2013). In that endeavour, he found an unlikely ally in the commander of the Fiji military forces, Commodore Frank Bainimarama, who had his own private grievance against the government besides genuine anger at proposed bills, in particular the Promotion of Reconciliation, Truth and Unity Bill, which could have granted amnesty to rebel soldiers involved in the mutiny in the military in November 2007, in which several loyalist soldiers had died.

Chaudhry did not use his considerable political weight to oppose the impending coup. As the late Michael Green, New Zealand's high commissioner to Fiji, put it, 'Chaudhry would not stand in the way

13 The 1997 Constitution provided that any political party with more than 5 per cent of seats in the House of Representatives was entitled to be invited into cabinet in proportion to its numbers. 
of a coup, let alone use his considerable influence to prevent one' (Green 2013, p. 168). Instead, he joined the military cabinet in early 2007. This was significant. Widely recognised as the leader of the IndoFijian community, his joining the regime cabinet brought considerable Indo-Fijian support to Bainimarama, bought him valuable time and helped him consolidate his position. A year and a half later, in August 2008, Chaudhry was forced out of the Bainimarama cabinet-left voluntarily, according to Chaudhry - and became a relentlessly vocal critic of the regime. But the regime had the last laugh. On the eve of the elections, Chaudhry was convicted of breaching the country's Foreign Exchange Act for failure to declare ownership of foreign currency without the express permission of the Reserve Bank. As a result of the conviction, he was barred from contesting the elections. Without him, the Labour Party was nothing. Its makeshift leader, former academic Rohit Kishore, was an unimpressive novice. The party, which had once won the hearts and minds of the Indo-Fijian community and formed the government of the country, had lost its peoples' affection and support. The reputation of its leader was now tarnished beyond repair. Indo-Fijians understandably saw no reason to vote for it.

The People's Democratic Party was formed by a group that had broken away from Chaudhry's Labour Party over disagreement about his leadership style. It included leading trade unionists. The PDP was genuinely multiracial and had members with fine talent but with little political experience beyond trade union circles. It lacked rural reach and political credibility too, in the eyes of many. The Fiji Trade Union Congress (FTUC) maintained a low profile in the early days of the coup, and general secretary Felix Anthony accepted his appointment to statutory boards by the military regime. For him to turn around now and condemn the regime sounded incongruous. Nonetheless, the party had socially progressive policies on law and justice and on protecting rights and freedoms, and about protecting workers' rights and media freedom, among many other policies. Such policies were in truth unexceptionable but they failed to impress the Indo-Fijian electorate attuned to other offers and other voices. PDP's policies on indigenous issues were sensitive and sensible, but they directly contradicted those of FijiFirst. The PDP declared in its manifesto that it 'respects the central place of iTaukei within Fiji's wider multicultural society and will pursue policies and programs consistent with the UN Indigenous Tribal and Peoples Convention'. FijiFirst's policy, which 
many Indo-Fijians found more appealing, placed everyone on an equal footing, not giving any group prior rights and privileges. On the GCC, the PDP recognised 'the important role of the GCC as an institution and the role of chiefs in modern Fiji'. Therefore, it would 'reinstate the GCC and will assist it to promote indigenous customs and traditions and to improve the economic well-being of indigenous people', while being guided by its advice 'on all matters relating to the protection of indigenous rights and interests'.

More Indo-Fijians were listening to FijiFirst on indigenous rights, which emphasised 'mainstreaming' indigenous practices. Aiyaz Sayed-Khaiyum had written about a 'sunset clause' on separate traditional institutions in his master's thesis at the University of Hong Kong, under the supervision of Professor Yash Ghai (who would later chair the ill-fated Fiji Constitution Commission, whose report was unceremoniously discarded by the Bainimarama regime). And most Indo-Fijians saw the GCC as a part of the problem, not part of the solution, remembering its support for previous coups and its being out of touch with the realities of a modern Fiji in a rapidly globalising world. The fact that the PDP was new on the scene with no track record did not help its cause. It won 15,864 (3.2 per cent) of the votes cast. Soon after the elections, its leader Felix Anthony rejoined FTUC, which under the present dispensation would prevent him from participating in electoral politics. Without his active participation at the helm, the party's future looks uncertain. It is likely to wither on the vine of public apathy and indifference.

Finally, there was the National Federation Party, which won 27,066 (5.5 per cent) of the votes and three seats in parliament, ending an absence of over a decade. The NFP is Fiji's oldest political party, founded in 1964, based in the Indo-Fijian community but with a non-racial platform, and in the vanguard of the movement for independence on the basis of a common roll. But it was communal representation which won the day and which was entrenched in the 1970 Constitution. Communal politics took root and racial divisions hardened to the point that a government elected with Indo-Fijian support was deposed in a military coup. The decreed 1990 Constitution entrenched racial apartheid. Nonetheless, the NFP leaders, principally Jai Ram Reddy, worked tirelessly with the Fijian leaders, principally the coup maker 
Sitiveni Rabuka, to produce a moderate, multiracial 1997 Constitution. It was a massive achievement in the most unlikely of circumstances, but its significance was not appreciated by Indo-Fijians.

The politics of moderation always loses in an atmosphere of polarised racial politics, and Fijian politics in the 1990s was deeply polarised. Both Rabuka and Reddy fell in the 1999 general elections. The NFP did not win a single seat then, or in the 2001 and 2006 elections. There was talk of closing shop, but the party persisted. It gained moderate momentum on the eve of the 2014 elections. It mattered that the party was led by a team untainted by a political past. Its leader was the academic economist Biman Prasad from USP, and its president was a young Fijian lawyer, Tupou Draunidalo. Her elevation to the presidency fulfilled the party's founding non-racial vision. In the party's line-up were several Fijian women and men with successful professional careers of their own. A decade or so ago, this would have been unthinkable, and likened to treachery. But it was to the party's credit that it had broadened its multiracial base to this extent. Its policies were principled, moderate and progressive, appealing more to the electorate's intellect than to its heart. Its credentials as a party of principle were credible. Like all other parties, the NFP had been in the wilderness for the previous eight years, and the military regime had done all it could to hobble its prospects. The constraints were considerable. So too were its achievements: three parliamentary seats, won in the most difficult of circumstances. The NFP has a future if it maintains its multiethnic character and outlook and continues to infuse fresh blood into the party.

Indo-Fijian support for FijiFirst was due not only to the weaknesses and constraints of other parties; it was also due to its own strengths and appeal. From 2007 onwards, despite the downturn in the economy, Bainimarama spared little effort to win popular support, including among Indo-Fijian voters, and the voting figures show he managed to do so to a large degree. He exploited the military regime's power of incumbency to the maximum, pointing to its record of achievements and making specific promises to the electorate, especially in the lower socioeconomic strata. Such promises had considerable attraction: an electricity subsidy for low-income families, water free of charge to those earning less than FJD\$30,000 a year, price control and removal of value-added tax on basic food items and pharmaceutical items, free milk to all first-year primary school children, streamlining the 
Tertiary Education Loan Scheme, providing free education to primary, secondary and pre-school students, and giving 99-year residential leases to squatters on state land were only some of the many promises the regime made, promises it was emphasised were backed by a record of achievements.

No other party could give such concrete promises and no other party would have been likely to be believed even if it did. While other parties struggled to get their messages through to the electorate, FijiFirst used the full extent of government machinery and the services of a compliant media to campaign. It helped the party's fortunes that all the district commissioners were former military men, along with many heads of government departments, some of who declared their intention to contest the elections within weeks of resigning their public service positions. This made a mockery of Commodore Bainimarama's promise at the time of the coup that no one in his administration would benefit politically or stand for elections. But no one seemed to be overly concerned about broken promises. It was all a part of the 'game' of politics. And in any case, it was said with no sense of irony at all that Bainimarama was standing not because he wanted to but because the people of Fiji would not have it any other way - and the will of the people had to reign supreme, over and above personal preferences. That, after all, was the essence of democracy.

After the elections, Indo-Fijians were commonly blamed for their shortsighted and self-centred choice and their unwillingness to consider the long-term implications of their actions. But it is understandable that Indo-Fijians, by choice as well as by necessity, voted the way they did. Taking a long-term view of democracy and governance is not a strong suit for a people struggling to make ends meet and keen to leave for other lands at the first opportunity. The best and the brightest of the Indo-Fijian community have left, are leaving, or will leave, leaving behind those who cannot migrate because they lack the skills or resources to do so. To them, the immediate fulfilment of their pressing daily needs was what mattered. By this criterion, FijiFirst had a clear advantage over its rivals. Democracy based on the will and whims of one strongman is dangerous, and Fiji may yet pay a heavy price for this; but for many this one strongman also stood for stability against chaos. Indo-Fijians knew well that if Bainimarama failed, they would be done for. More than anything else, ordinary people wanted peace and security, and insurance against future coups. Bainimarama offered 
to be the buffer, and he was believed. But what happens when the well runs dry, or when some other saviour appears on the horizon, who has a different agenda, a different vision, perhaps even a nationalistic one? Does the military, for all practical purposes an indigenous institution itself, really have a multiracial vision? Do the Commodore's own supporters, many of whom were in previous coup camps, have such a vision? In 2014, Indo-Fijians made the pragmatic assessment that, for the moment, Bainimarama, with the military solidly behind him, was their man. Tomorrow, as they say, is another day.

Democracy has had an ill-fated history in Fiji, having to contend with military coups as the vehicle for effecting political change in the country. Democracy was alive all these years more in its symbolism than in its substance, dependent on the goodwill of powerful men rather than implanted in the hearts of ordinary citizens or embedded in the sinews of its public institutions. It had few true defenders but many fair weather friends, who habitually deserted it in its moments of greatest need. Democratic values have been steadily eroding in Fiji since the 1987 coups and disillusionment with politics and politicians. All this made the Indo-Fijian reaction in 2014 understandable, but it is also true that Indo-Fijians have planted in the process the seeds of a new political order, a new kind of democracy, which is fundamentally at odds with the principles of representative democracy. Putting it colloquially, placing all your eggs in one basket in an uncertain environment is never prudent; nor is it prudent to pin all your hopes on one man to be your saviour, however good or great that saviour might turn out to be. The rule of law, freely arrived at, is infinitely superior to the rule of a group of men, however well intentioned they might be. Fiji is going through a massive process of transition from one order to another. Inevitably, there will be uncertainty, confusion, error, disenchantment and disappointment. The larger question is whether, to borrow words from Rosencrantz and Guildenstern are Dead, the exit from one place will lead to an entrance somewhere else. For the sake of Fiji, one hopes it will be entrance to a better place. That remains to be seen, but is something very much to be hoped for. 


\section{References}

Ali, Ahmed 1973, 'The Fiji General elections of 1972', The Journal of Pacific History, vol. 8, pp. 171-80.

Ali, Ahmed 2007, Fiji and the franchise: A history of political representation, 1900-1937, iUniverse, Indiana.

Chetty, Kishor Nand and Prasad, Satendra 1993, Fiji's Emigration: An examination of contemporary trends and issues, University of the South Pacific, Suva.

Firth, Stewart 2012, 'Reflections on Fiji since Independence', Round Table: The Commonwealth Journal of International Affairs, vol. 101, no. 6, pp. 575-83.

Fraenkel, Jon 2015, 'The remorseless power of incumbency in Fiji's September 2014 election', The Round Table: The Commonwealth Journal of International Affairs, vol. 104, no. 2, pp. 151-64.

Fraenkel, Jon, Firth, Stewart, and Lal, Brij V (eds) 2009, The 2006 Military Takeover in Fiji: A coup to end all coups, ANU E Press, Canberra.

Green, Michael 2013, Persona non grata: Breaking the bond: Fiji and New Zealand, 2004-2007, Dunmore Publishing, Auckland.

Kant, Romitesh and Rakuita, Eroni 2014, 'Public participation \& constitution-making in Fiji: A critique of the 2012 constitutionmaking process', State, Society and Governance in Melanesia Program Discussion Paper 6, The Australian National University.

Lal, Brij V 1992, Broken Waves: A history of Fiji in the 20th century, University of Hawaii Press, Honolulu.

Lal, Brij V 1997. A vision for change: AD Patel and the politics of Fiji, Asia Pacific Press, Canberra.

Lal, Brij V 2006a, Islands of turmoil: Elections and politics in Fiji, Asia Pacific Press, Canberra.

Lal, Brij V 2006b (ed.), Fiji: British documents on the end of empire, The Stationery Office, London. 
Lal, Brij V 2009a, 'One hand clapping: Reflections on the first anniversary of Fiji's 2006 coup', in John Fraenkel, Stewart Firth and Brij Lal (eds), The 2006 Military takeover in Fiji: A coup to end all coups? ANU E Press, Canberra, pp. 425-48.

Lal, Brij V 2009b. In the eye of the storm: Jai Ram Reddy and the politics of Fiji, Asia Pacific Press, Canberra.

Lal, Brij V 2013, 'The strange career of Commodore Frank Bainimarama's 2006 Fiji coup', State, Society and Governance in Melanesia Program Discussion Paper 8, The Australian National University.

Lal, Brij V 2014, 'In Frank Bainimarama's shadow: Fiji, elections and the future', Journal of Pacific History, vol. 49, no. 4, pp. 457-68.

Lal, Padma Narsey 2008, Ganna: Portrait of the Fiji sugar industry, Fiji Sugar Commission, Lautoka.

Larson, Eric 2014, 'Fiji's 2014 parliamentary election', Journal of Electoral Studies, December 2014, pp. 235-39.

Norton, Robert 2000, 'Reconciling ethnicity and nation: Contending discourses in Fiji constitutional reform', The Contemporary Pacific, vol. 12, no. 1, pp. 83-122.

Norton, Robert 2012, 'A pre-eminent right to political rule: Indigenous Fijian power and the multi-ethnic nation building', Round Table: The Commonwealth Journal of International Affairs, vol. 101, no. 6, pp. 537-55.

Reeves, Sir Paul, Vakatora, Tomasi Rayal and Lal, Brij V 1996. Towards a united future: Report of the Fiji Constitution Review Commission, Parliament of Fiji, Suva.

Scarr, Deryck 2008, Tuimacilai: A life of Ratu Sir Kamisese Mara, Crawford House, Adelaide.

Sharpham, John 2000, Rabuka of Fiji: The authorized biography of Major General Sitiveni Rabuka, Central Queensland University Press, Rockhampton.

Taylor, Michael (ed.) 1987, Fiji: Future imperfect, Allen \& Unwin, Sydney. 
This text is taken from The People Have Spoken: The 2014 Elections in Fiji, edited by Steven Ratuva and Stephanie Lawson, published 2016 by ANU Press, The Australian National University, Canberra, Australia. 